\title{
Uang Kuliah di Masa Pandemi: Mendaras SK Rektor UIN AM tentang Keringanan UKT Mahasiswa
}

\begin{abstract}
Askar Nur
askarr.nur@gmail.com

Bahasa dan Sastra Inggris, Fakultas Adab dan Humaniora, Universitas Islam Negeri Alauddin

Makassar

Abstrak

Artikel ini menganalisis Surat Keputusan Rektor UIN Alauddin Makassar tentang keringanan UKT mahasiswa di masa pandemi. Penulis menemukan bahwa keringanan UKT 10\% selama pandemi sangatlah kurang berdasarkan pertimbangan situasi dan kondisi di masa pandemi yang hampir setiap sektor berada pada titik krisis. Pandemi Covid-19 merupakan sebuah kondisi di mana kerugian tidak dapat dihindari dan di luar batas kemampuan manusia (force majeure).
\end{abstract}

Kata kunci: UKT, Covid-19, Force Majeure, Keringanan 10\%

\section{Pendahuluan}

Pada masa pandemi seperti saat ini, himbauan atau instruksi bahkan kebijakan acapkali dikeluarkan oleh para aparatur dan instrumen negara. Hampir semuanya lepas kendali terhadap pertimbangan kondisi sosial kemasyarakatan. Hal demikian dapat disimak dari beberapa kebijakan yang dikeluarkan dari sektor pendidikan seperti pengalihan perkuliahan sistem daring dan keringanan pembayaran uang kuliah mahasiswa.

Meminjam metafor dari Koestler, Shore dan Wright (1997:5) mengatakan bahwa kebijakan itu ,entah himbauan atau instruksi, adalah seperti "the ghost in mechine", sebuah kekuatan yang meniupkan kehidupan dan tujuan ke dalam mesin pemerintahan dan menghidupkan tangan yang sudah mati dari suatu birokrasi. 
Lebih jauh, kebijakan harus tetap mempertimbangkan wilayah kajian antropologi agar apa yang dibahasakan oleh Foucault, 'where there is power, there is resistance'. Perkara demikian tentu akan berlaku jikalau kebijakan yang hadir dinilai oleh masyarakat tidak mengakomodir kepentingan universal. Resistensi terhadap kebijakan merupakan bentuk diagnostik kekuasaan.

\section{Pembahasan}

Mencermati SK Rektor No. 491 tentang Keringanan UKT Mahasiswa di Lingkungan UIN Alauddin Makassar atas Dampak Covid-19 yang terbit pada 25 Juni 2020 terdapat beberapa diktum yang harus didiskusikan secara ilmiah, kritis dan transparansi. Dalam SK tersebut menyebutkan pada diktum kedua mengenai mekanisme keringanan yang dapat ditempuh mahasiswa, yakni keringanan $10 \%$, perpanjangan masa pembayaran, cicilan pembayaran bebas bunga dan pembebasan uang kuliah.Poin yang menjadi perhatian tersendiri pada mekanisme tersebut adalah mengenai keringanan $10 \%$ dan pembebasan uang kuliah tapi bukan berarti mengabaikan yang lainnya.

\section{Keringanan $10 \%$ atau UKT Gratis?}

Selanjutnya, penentuan keringanan $10 \%$ pada setiap nominal UKT mahasiswa tentu (seharusnya) tidak terlepas dari perhitungan unit cost merujuk pada SSBOPT dan BOPT yang menjadi pertimbangan dalam penentuan UKT sesuai amanah PMA No. 7 tahun 2018 pada pasal 8 (1). Dan perhitungan SSBOPT berdasar pada BOPT, indeks mutu PTKN dan indeks mutu program studi, indeks pola pengelolaan keuangan dan indeks kemahalan wilayah.

Sementara itu, BOPT diperoleh dari Biaya Langsung (BL) dan Biaya Tidak Langsung (BTL) dimana keduanya masing-masing memiliki komponen. BL atau sederhananya adalah biaya untuk keperluan belajar mengajar terdiri atas kegiatan kelas (seperti kuliah tatap muka, UTS, UAS), kegiatan laboratorium/studio/bengkel/lapangan (seperti pratikum, penggunaan laboratorium, kuliah lapangan, KKN), kegiatan tugas akhir/proyek akhir/skripsi (seperti ujian akhir, proyek akhir, ujian komprehensif dan seminar) dan bimbingan-konseling dan kemahasiswaan (seperti bimbingan akademik, orientasi mahasiswa baru, pengembangan diri).

Adapun BTL terdiri atas biaya administrasi umum (seperti gaji dan tunjangan tenaga kependidikan, tunjangan tambahan untuk dosen yang menduduki jabatan struktural, bahan habis 
pakai, perjalanan dinas), pengoperasian dan pemeliharaan/perbaikan sarana dan prasarana (seperti pemeliharaan/perbaikan gedung, jalan lingkungan kampus dan peralatan, bahan bakar generator dan angkutan kampus, utilitas (air, listrik, telepon), langganan bandwidth koneksi internet), pengembangan institusi (seperti penyusunan renstra dan RKAT, operasional senat, pengembangan koleksi perpustakaan) dan biaya operasional lainnya (seperti pelatihan dosen dan tenaga kependidikan, perjalanan dinas, penjaminan mutu).

\section{Kesimpulan}

Sampai di sini, kita dapat melayangkan pertanyaan spekulatif, apakah keringanan 10\% diperoleh dari perkara terealisasinya seluruh komponen BL dan BTL dalam UKT? Tentu pertanyaan spekulatif ini harus bertemu dengan jawaban reflektif. Di masa pandemi ini, segala hal yang menyangkut keterlibatan banyak orang dialihkan ke sistem online termasuk perkuliahan online sementara komponen BL dan BTL dalam UKT hanya dapat terealisasikan melalui sistem luring (tatap muka langsung), jika segala aktivitas dialihkan ke sistem online maka dapat dipastikan komponen dalam UKT tidak terpakai khususnya BL. Pada kasus ini, kita tidak sedang menyalahkan kondisi pandemi tentunya melainkan lebih ke arah menyesuaikan dengan yang seharusnya terjadi.

Sebagai bahan dasar dalam logika persenan, kita dapat mengatakan bahwa item-item dalam BL adalah $50 \%$ begitupun dengan BTL jadi keduanya bernilai $100 \%$. BL pada perkuliahan online dapat dipastikan keseluruhan item tidak terealisasi, sementara BTL sebagai biaya yang tidak berkaitan langsung dengan proses belajar mengajar tentu tidak terealisasikan pula secara keseluruhan berdasarkan list item di atas. Maka tentu kita dapat berkesimpulan bahwa 100\% komponen dalam UKT tidak terealisasikan, kendati demikian seharusnya UKT pada masa pandemi dibebaskan (gratis) dengan pertimbangan tersebut. Bahasa kasarnya adalah tentu kita tidak seharusnya membayar sesuatu yang tidak kita nikmati dan keringanan $10 \%$ bukanlah keputusan yang berkeadilan.

Begitupula dengan pembebasan UKT yang hanya berlaku bagi pihak yang membiayai mahasiswa meninggal dunia karena pandemi. PMA No. 7 tahun 2018 memberikan pendefinisian terhadap UKT sebagai biaya yang ditanggung mahasiswa sesuai kemampuan ekonomi orang 
tua. Artinya pembebasan UKT dengan persyaratan seperti dalam SK tersebut tentu melenceng dari wilayah definitif UKT.

Pembebasan UKT seharusnya berlaku secara menyeluruh tanpa syarat di masa pandemi ini. Pandemi Covid-19 menyerang secara keseluruhan tanpa melihat identitas atau kelas sosial tiap individu dan dapat dipastikan perekonomian berada pada titik nadir. Kita semua berada dalam kondisi kahar, sebuah kondisi di luar kemampuan manusia dan kerugian tak terhindarkan.

Tulisan ini pernah dimuat di Opini Harian Tribun Timur

\section{Daftar Pustaka}

Shore and Wright (1997). Anthropology of Policy: Perspectives on Governance and Power (European Association of Social Anthropologists). Routledge; 1st Edition

Rouse, J. (1994). Power/knowledge. The Cambridge Companion to Foucault, 2.

Surat Keputusan Rektor No. 491 tentang Keringanan UKT Mahasiswa di Lingkungan UIN Alauddin Makassar atas Dampak Covid-19 yang terbit pada 25 Juni 2020

PMA No. 7 tahun 2018 tentang SSBOPT 